\title{
ETV5 wt Allele
}

National Cancer Institute

\section{Source}

National Cancer Institute. ETV5 wt Allele. NCI Thesaurus. Code C97480.

Human ETV5 wild-type allele is located in the vicinity of 3q28 and is approximately $64 \mathrm{~kb}$ in length. This allele, which encodes ETS translocation variant 5 protein, is involved in transcriptional regulation. Chromosomal translocations of this gene and either the TMPRSS2 gene or the SLC45A3 gene are associated with prostate cancer. 